\title{
FAKTOR YANG MEMPENGARUHI KECURANGAN LAPORAN KEUANGAN DENGAN PERSPEKTIF FRAUD TRIANGLE (Studi Empiris pada Perusahaan Property, Real Estate dan Building Construction)
}

\author{
Yohannes Suharsana ${ }^{1}$, Chatarina Prisiena ${ }^{2}$ \\ Prodi Akuntansi Sekolah Tinggi Ilmu Ekonomi Gentiaras Lampung \\ Email: y.suharsana@gmail.com
}

\begin{abstract}
This research is to analyzed influence of variable pressure which proxied by financial stability, external pressure, and financial target, and then variable opportunity which proxied by nature of industry, ineffective monitoring, and variable razionalization which proxied by auditor change with fraudulent financial statement which measured with fraud score model (F-Score).

The sample used in this research are 26 companies of property, real estate, and building construction sector that listed in Indonesian Stock Exchange on the period 2011 to 2015. The type data that used are secondary data, from the annual reports of companies sample.

The result of this statistical research showed that the variables of financial stability that measured with change in total asset ratio, financial target variable that measured with ROA (return on assets), and nature of industry variable that measured with the change in receivables ratio has positive influence on the fraudulent financial statement. The research does not prove that external pressure variable which measured with leverage ratio, ineffective monitoring variable which measured with the percentage of board members who are outside members, and change auditor which measure with dummy variable has an influence on the fraudulent financial statement.
\end{abstract}

Keyword: Fraudulent financial statement, Fraud triangle, F-Score

\section{PENDAHULUAN}

\subsection{Latar Belakang}

Isu mengenai kecurangan dalam kurun waktu sepuluh tahun terakhir ini marak menjadi perbincangan terutama menyangkut pada skandal keuangan dalam suatu usaha. Adanya persaingan menggencarkan pemilik usaha untuk memperoleh keuntungan yang terus meningkat. Strategi handal kemudian diluncurkan oleh manajemen untuk menempatkan usaha agar tetap likuid. Namun, di luar dari teraturnya strategi, ada kalanya strategi yang digunakan menyeret suatu usaha melewati garis batas kewajaran. Tidak hanya dilakukan oleh badan usahanya, ada juga pelaku usaha yang melakukan tindak penyelewengan untuk keuntungan pribadi, mulai dari low management bahkan sejumlah spekulasi menyebutkan pelakunya sampai pada top management.
Tindakan merugikan tersebut saat ini dikenal dengan istilah fraud atau kecurangan atau penipuan. Fraud dan korupsi merupakan dua istilah yang berbeda namun masuk ke dalam satu kasus yang berkaitan. Apabila fraud terjadi, maka korupsi juga ada di dalamnya. Jika fraud adalah penipuan yang dibuat untuk mendapatkan keuntungan pribadi atau untuk merugikan orang lain atau suatu tindak kesengajaan untuk menggunakan sumber daya perusahaan secara tidak wajar dan salah menyajikan fakta untuk memperoleh keuntungan pribadi (Christofel, 2010).

Semakin banyaknya kasus kecurangan keuangan yang terjadi di dunia terutama kasus yang menyangkut akuntansi keuangan, akan menjadi masalah signifikan. Tidak hanya usaha kecil yang mudah terlibat dalam berbagai kasus, tetapi usaha besar menjadi sorotan utama dalam penyelidikan indikasi kecurangan. 
Tabel 1.

Kasus Kecurangan yang Terjadi di Berbagai Negara

\begin{tabular}{|c|c|c|}
\hline Negara & Perusahaan & Kasus \\
\hline Indonesia & PT. Sentul City, Tbk & $\begin{array}{l}\text { Ditetapkan direktur utama, sebagai tersangka korupsi, terkait } \\
\text { kasus konversi hutan di Kabupaten Bogor. Selain itu, tahun } \\
2005 \text { perusahaan ini digugat pailit oleh konsumennya Azelia } \\
\text { Birrer terkait keterlambatan serah terima untuk obyek perikatan } \\
\text { jual beli tanah dan bangunan di klaster R-21, perumahan Sentul } \\
\text { City, Bogor yang telah dibayar lunas oleh konsumen. } \\
\text { (Kompas.com dalam Annisya, 2016). }\end{array}$ \\
\hline Indonesia & Bank BNI & $\begin{array}{l}\text { Kasus L/C fiktif dan pembobolan di beberapa cabang BNI } \\
\text { (Gusnardi, 2012). }\end{array}$ \\
\hline Indonesia & PT. Kimia Farma & $\begin{array}{l}\text { Pada } 31 \text { Desember 2001, PT. Kimia Farma melakukan } \\
\text { kecurangan laporan keuangan yang berupa salah saji laba } \\
\text { bersih untuk periode } 31 \text { Desember } 2001 \text {. Perusahaan ini juga } \\
\text { melakukan pencatatan ganda atas penjualan dua unit usaha. } \\
\text { Perusahaan ini memanipulasi data keuangan dan laporan } \\
\text { keuangannya dengan tujuan untuk menunjukan keadaan } \\
\text { keuangan perusahaan tetap baik dan stabil. (kompasiana.com } \\
\text { dalam Annisya, 2016). }\end{array}$ \\
\hline Indonesia & Bank BRI & Kasus pembobolan senilai Rp 294 miliyar (Gusnardi, 2012). \\
\hline Indonesia & $\begin{array}{l}\text { PT. Kereta Api } \\
\text { Indonesia }\end{array}$ & $\begin{array}{l}\text { Penjualan aset perusahaan berupa gerbong kuno yang hasil } \\
\text { penjualannya masuk ke kantong pribadi dan pengalihfungsian } \\
\text { tanah milik perusahaan menjadi pusat perbelanjaan (Sri Ayu, } \\
\text { 2012). }\end{array}$ \\
\hline $\begin{array}{l}\text { Amerika } \\
\text { Serikat }\end{array}$ & Enron & $\begin{array}{l}\text { Utang perusahaan yang tersembunyi dan keuntungan yang } \\
\text { meningkat lebih dari } 1 \text { miliyar US\$. (Pardosi, 2014). }\end{array}$ \\
\hline Jepang & Olympus & $\begin{array}{l}\text { Melakukan penipuan mencantumkan laba yang besar pada } \\
\text { laporan keuangan dan menyembunyikan kerugian investasi } \\
\text { selama lebih dari satu dekade. Akibatnya, perusahaan } \\
\text { elektronik asal Jepang ini mengalami kemunduran. (Fahrudin, } \\
\text { 2014). }\end{array}$ \\
\hline $\begin{array}{c}\text { Amerika } \\
\text { Serikat }\end{array}$ & Worldcom & $\begin{array}{l}\text { Total pengeluaran operasional normal senilai USD } 3,8 \text { miliar } \\
\text { yang seharusnya dicatat sebagai pengeluaran untuk tahun } \\
\text { keuangan berlangsung, diperlakukan sebagai investasi dan } \\
\text { dihitung untuk bertahun-tahun. Tahun 2001, memanipulasi } \\
\text { keuntungan USD } 1,3 \text { miliar. (Detik Finance dalam Annisya, } \\
\text { 2016). }\end{array}$ \\
\hline
\end{tabular}

Sumber: Beberapa Literatur Penelitian dan Media Online

Penelitian ini merupakan replikasi dan pengembangan dari penelitian Hanum (2014) dengan perbedaan 1) Periode Penelitian 2) Objek Penelitian3) Variabel Penelitian. Hanum (2014) menggunakan tiga variabel independen dalam penelitian yaitu variabel financial stability variabel proksi dari pressure yang diukur dengan rasio perputaran total aset
(ACHANGE), variabel ineffective monitoring, variabel proksi dari opportunity yang diukur dengan proporsi jumlah dewan komisaris independen (BDOUT), dan variabel auditor change (AUDCHANGE), variabel proksi dari rationalization yang diukur dengan variabel dummy. 
Sementara penelitian ini menambah variabel sesuai dengan saran penelitian tersebut agar penelitian dapat lebih maksimal. Variabel independen yang ditambahkan yaitu pada variabel proksi pressure berupa variabel external pressure yang diukur dengan rasio leverage (LEV), variabel financial target yang diukur dengan Return on Total Assets (ROA) dan pada variabel proksi opportunity berupa variabel nature of industry yang diukur dengan rasio perputaran piutang (RECEIV).

Sehingga total variabel independen pada penelitian ini sebanyak enam variabel dengan penjabaran berupa variabel proksi pressure yaitu financial stability diukur dengan rasio perubahan total aset (ACHANGE), external pressure diukur dengan rasio leverage (LEV), financial target diukur dengan Return on Total Assets (ROA), pada variabel proksi opportunity yaitu nature of industry diukur dengan rasio perputaran piutang (RECEIV), ineffective monitoring diukur dengan proporsi jumlah dewan komisaris independen (BDOUT) dan pada variabel proksi rationalization yaitu auditor change (AUDCHANGE) yang diukur dengan dummy variable.

\subsection{Perumusan Masalah}

1. Apakah variabel financial stability, variabel proksi dari pressure yang diukur dengan rasio perubahan total aset (ACHANGE) berpengaruh postif dan signifikan terhadap kecurangan laporan keuangan?

2. Apakah variabel external pressure, variabel proksi dari pressure yang diukur dengan kemampuan perusahaan dalam memenuhi kewajibannya (LEV) berpengaruh positif dan signifikan terhadap kecurangan laporan keuangan?

3. Apakah variabel financial targets, variabel proksi dari pressure yang diukur dengan rasio kemampuan perusahaan memenuhi laba $(R O A)$ berpengaruh positif dan signifikan terhadap kecurangan laporan keuangan?

4. Apakah variabel nature of industry, variabel proksi dari opportunity yang diukur dengan perhitungan rasio perputaran piutang

(RECEIV) berpengaruh positif dan signifikan terhadap kecurangan laporan keuangan?

5. Apakah variabel ineffective monitoring, variabel proksi dari opportunity yang diukur dengan proporsi jumlah dewan komisaris independen (BDOUT) berpengaruh positif dan signifikan terhadap kecurangan laporan keuangan?

6. Apakah variabel perubahan auditor (AUDCHANGE), variabel proksi dari rationalization yang diukur dengan dummy variable berpengaruh positif dan signifikan terhadap kecurangan laporan keuangan?

\section{TINJAUAN PUSTAKA}

\subsection{Teori Kecurangan (Fraud)}

Dalam literatur akuntansi dan auditing, fraud diterjemahkan sebagai praktik kecurangan dan fraud sering diartikan sebagai irregularity atau ketidakteraturan dan penyimpangan. Terdapat banyak definisi dan pengertian fraud. Salah satu definisi fraud adalah definisi menurut Black's Law Dictionary8th Edition dalam (Hanifa, 2015) yaitu suatu perbuatan sengaja untuk menipu atau membohongi, suatu tipu daya atau cara-cara yang tidak jujur untuk mengambil atu menghilangkan uang, harta, hak yang sah milik orang lain baik karena suatu tindakan atau dampak yang fatal dari tindakan itu sendiri.

\subsection{Teori Fraud Triangle}

Gambar 1.

Fraud Triangle

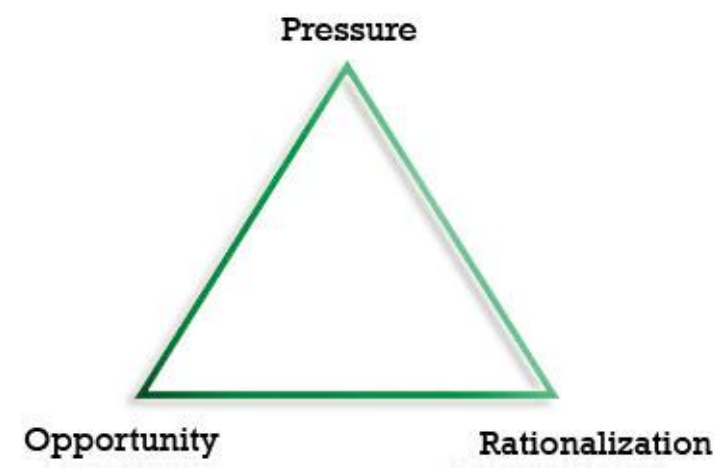

Sumber: Cressey (1953) dalam Skousen et al.,(2008) 
Salah satu penjelasan teoritis mengenai tindakan kecurangan, yaitu teori faktor risiko kecurangan yang disampaikan oleh Donald Cressey (1953) bahwa seseorang bisa melakukan tindakan kecurangan pada umumnya dilandasi oleh tiga elemen yaitu tekanan atau insentif (pressure), kesempatan (opportunity), dan rasionalisasi (rationalization). Ketiganya mendukung satu sama lain dalam membentuk dasar terjadinya kecurangan. Ketiga elemen tersebut disebut sebagai fraud triangle oleh Cressey (1953) dalam Skousen et al., (2008).

Menurut Statement of Auditing Standards No.99 (SAS no.99) dalam Skousen et al., (2008), ada empat jenis umum dari pressure yang menyebabkan kecurangan laporan keuangan. Kondisi tersebut adalah financial stability, external pressure, personal financial need, dan financial targets.

1) Stabilitas Keuangan (Financial Stability); Financial stability merupakan keadaan keuangan perusahaan dalam kondisi stabil. Beberapa proksi variabel untuk mengukur financial stability yaitu Gross Profit Margin (GPM), perubahan penjualan (SCHANGE),Perubahan aset dua tahun sebelum pelanggaran (ACHANGE), pertumbuhan penjualan (CATA), SALAR, SALTA, INVSAL.

2) Tekanan Eksternal (External Pressure); Dalam variabel proksi ini digunakan beberapa pengukuran yaitu, rasio leverage (LEV), FINANCE, dan Free Cash Flow (FREEC).

3) Kebutuhan Keuangan Pribadi (Personal Financial Need); Variabel proksi ini diukur menggunakan \% kepemilikan saham mayoritas (OSHIP), dan \% kepemilikan saham direksi $(5 \% \mathrm{OWN})$.

4) Target Keuangan (Financial Target); Skousen et al., (2008) mengatakan bahwa Return on Total Asset (ROA) adalah ukuran kinerja operasional yang banyak digunakan untuk menunjukkan seberapa efisien aset yang telah digunakan.

Kesempatan (Opportunity); Gagola

(2011) dalam Ratmono dan Diany (2014) mengatakan bahwa kesempatan akan timbul saat sistem pengendalian internal perusahaan lemah sehingga akan memiliki banyak celah yang menjadikan kesempatan bagi manajemen untuk memanipulasi transaksi. 1) Kondisi Industri (Nature of Industry); 2) Pengawasan yang Tidak Efektif (Ineffective Monitoring); 3) Struktur Organisasi (Organizational Structure)

Rasionalisasi (Rationalization) 1) Perubahan Auditor (Auditor Change); 2) Opini Audit. Berdasarkan penjelasan di atas, berikut ringkasan penjabaran variabel-variabel penelitian Skousen et al., (2008) pada fraud triangle dalam tabel yang telah diterjemahkan di bawah ini:

Tabel 2.

Proksi Faktor Risiko Kecurangan

\begin{tabular}{|c|c|c|c|}
\hline $\begin{array}{l}\text { Fraud Risk } \\
\text { Factors }\end{array}$ & $\begin{array}{l}\text { SAS No. } 99 \\
\text { Categories }\end{array}$ & Proxies & Definition of proxies \\
\hline \multirow{9}{*}{$\begin{array}{l}P \\
R \\
E \\
S \\
S \\
U \\
R \\
E\end{array}$} & \multirow{7}{*}{ Financial Stability } & GPM & Gross Profit Margin \\
\hline & & SCHANGE & $\begin{array}{l}\text { Perubahan Penjualan } \quad \text {-Perubahan } \\
\text { Penjualan Rata-Rata Industri }\end{array}$ \\
\hline & & ACHANGE & $\begin{array}{l}\text { Perubahan aset selama dua tahun } \\
\text { sebelum fraud. }\end{array}$ \\
\hline & & CATA & $\begin{array}{l}\text { Pendapatan operasi - Arus Kas } \\
\text { Operasi / Total Aset }\end{array}$ \\
\hline & & SALAR & Penjualan / Piutang \\
\hline & & SALTA & Penjualan / Total Aset \\
\hline & & INVSAL & Persediaan / Total Penjualan \\
\hline & \multirow[b]{2}{*}{ External Pressure } & LEV & Total Utang / Total Aset \\
\hline & & FINANCE & $\begin{array}{l}\text { Kas dari operasional - Modal Rata- } \\
\text { Rata Ekspenditur t-3 to t-1/ Aset Lancar }\end{array}$ \\
\hline
\end{tabular}




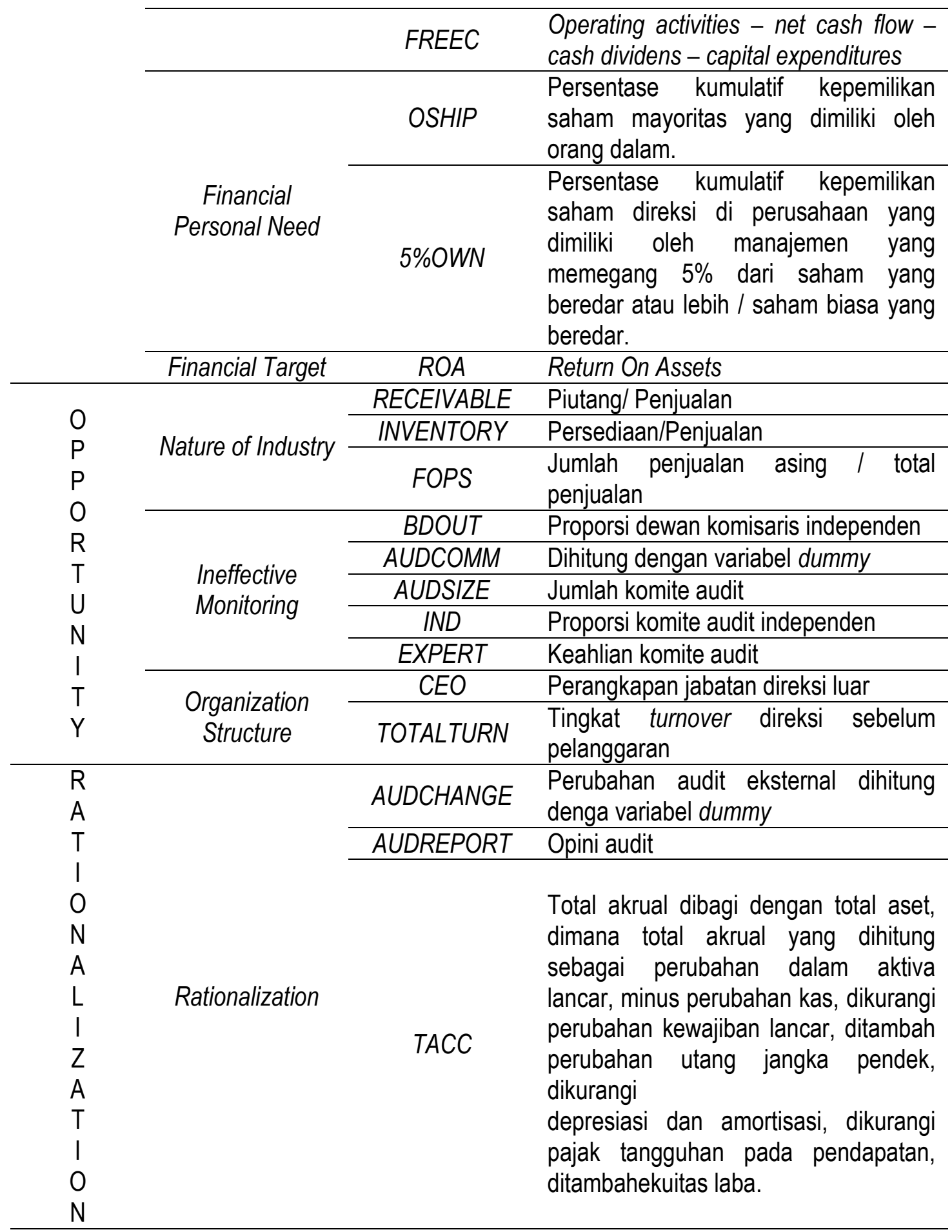

Sumber: Penelitian oleh Skousen et. al. (2008)

\subsection{Hipotesis}

$\mathrm{H} 1$ : Financial stability dengan proksi rasio perubahan total aset (ACHANGE) berpengaruh positif dan signifikan terhadap kecurangan laporan keuangan.

H2 : External Pressure dengan proksi leverage ratio berpengaruh positif dan signifikan terhadap kecurangan laporan keuangan.

H3 : Financial Target dengan proksi return on assets (ROA) berpengaruh positif dan signifikan terhadap kecurangan laporan keuangan.

$\mathrm{H} 4$ : Nature of industry dengan proksi rasio perubahan piutang berpengaruh positif 
dan signifikan terhadap kecurangan laporan keuangan.

H5 : Ineffective monitoring dengan proksi proporsi dewan komisaris independen (BDOUT) berpengaruh positif dan signifikan terhadap kecurangan laporan keuangan.

H6 : Pergantian auditor berpengaruh positif dan signifikan terhadap kecurangan laporan keuangan.

\section{METODE PENELITIAN}

\subsection{Jenis Penelitian}

Penelitian Deskriptif Kuantitatif, Penelitian deskriptif adalah penelitian yang dilakukan untuk mengetahui nilai variabel madiri, baik satu variabel atau lebih (independen) tanpa membuat perbandingan, atau menghubungkan dengan variabel yang lain. Penelitian kuantitatif adalah penelitian dengan memperoleh data yang berbentuk angka termasuk data berskala ukur interval dan rasio. Berdasarkan teori di atas, maka jenis penelitian yang dipakai adalah penelitian deskriptif kuantitatif.

\subsection{Teknik Pengumpulan Data}

Dalam suatu penelitian, terdapat tiga pendekatan yang dapat digunakan, yaitu kuantitatif, kualitatif, dan gabungan dari keduanya. Metode yang digunakan dalam penelitian ini adalah metode kuantitatif, dimana penelitian ini berupa analisis fraud score model (F-Score) terhadap proksi-proksi yang dianggap menjadi penyebab terjadinya kecurangan laporan keuangan (fraudulent financial statement) dengan menggunakan angka-angka sebagai indikator variabel penelitian untuk menjawab permasalahan penelitian.

\subsection{Teknik Analisis Data}

Penelitian ini menggunakan uji statistik deskriptif. Statistik deskriptif dalam penelitian pada dasarnya merupakan proses transformasi data penelitian dalam bentuk tabulasi sehingga mudah dipahami dan diinterpretasikan (Indriantoro dan Supomo, 1999:170). Analisis ini digunakan untuk menganalisis dan menyajikan data yang bersangkutan. Hasil dari analisis deskriptif, baik per perusahaan maupun kelompok perusahaan dapat menggambarkan tingkat risiko kecurangan laporan keuangan.

Analisis regresi linear berganda adalah analisis untuk mengukur besarnya pengaruh antara dua atau lebih variabel independen terhadap satu variabel dependen dan menprediksi variabel dependen dengan menggunakan variabel independen. Dalam regresi linear berganda terdapat asumsi klasik yang harus terpenuhi, yaitu residual terdistribusi normal, tidak adanya multikolinearitas, tidak adanya heteroskedastisitas, dan tidak adanya autokolerasi pada model regresi. Analisis regresi digunakan untuk menjawab permodelan yang dibangun. Untuk menilai kelayakan model (Godness of Fit Test) dilakukan dengan koefisien determinasi, Uji F, dan Uji t.

1) Koefisien Determinasi $R^{2}$; Koefisien determinasi pada intinya mengukur seberapa jauh kemampuan model dalam menerangkan variasi variabel independen (Ghozali, 2009). Nilai koefisien determinasi adalah antara nol dan satu. Nilai $R^{2}$ yang kecil berarti kemampuan variabel-variabel independen dalam menjelaskan variasi variabel dependen sangat terbatas. Nilai yang mendekati 1 berarti variabel-variabel independen memberikan hampir sama semua informasi yang dibutuhkan untuk memprediksi variasi variabel independen.

2) Uji $F$ atau uji koefisien regresi secara bersama-sama digunakan untuk mengetahui apakah secara bersama-sama variabel independen berpengaruh signifikan terhadap variabel dependen. Pengujian menggunakan tingkat signifikansi 0,05 dengan melihat tabel $F$ (lihat lampiran 15) dengan df 1 (jumlah variabel-1) dan df 2 (n-k-1), $n$ adalah jumlah data, sedangkan $k$ merupakan jumlah variabel independen. Kriteria pengujian yaitu:
a) Jika $F$ hitung $\leq F$ tabel maka $\mathrm{Ho}$ ( $X$ tidak berpengaruh terhadap $Y$ ) diterima.
b) Jika $F$ hitung $>F$ tabel maka Ho ( $X$ tidak berpengaruh terhadap $Y$ ) ditolak.


3) Uji t; Uji t atau uji koefisien regresi secara parsil digunakan untuk mengetahui apakah secara parsial variabel independen berpengaruh secara signifikan atau tidak terhadap variabel dependen. Pengujian menggunakan tingkat signifikansi 0,05 dan 2 sisi. $t$ tabel dapat dicari pada signifikansi $0,05 / 2=0,025$ (uji 2 sisi) dengan derajat kebebasan $\mathrm{df}=\mathrm{n}-\mathrm{k}-$

1. (Lihat pada lampiran 16). Kriteria pengujian pada uji t yaitu:

a) Jika $-t$ tabel $\leq t$ hitung $\leq t$ tabel maka Ho (variabel independen tidak berpengaruh terhadap variabel dependen) diterima.

b) Jika - t hitung <-t tabel atau thitung > $t$ tabel maka Ho (variabel independen tidak berpengaruh terhadap variabel dependen) ditolak.

\section{HASIL PENELITIAN DAN PEMBAHASAN}

\subsection{Uji Regresi}

Analisis data dalam penelitian ini menggunakan analisis regresi berganda. Analisis regresi digunakan untuk menjawab permodelan yang dibangun. Untuk menilai kelayakan model (Godness of Fit Test) dilakukan dengan koefisien determinasi, Uji $F$, dan Uji t.

\section{Koefisien Determinasi $\left(R^{2}\right)$}

Koefisien determinasi pada intinya mengukur seberapa jauh kemampuan model dalam menerangkan variasi variabel independennya (Hanum, 2014). Nilai koefisiensi determinasi adalah antara nol dan satu. Berikut hasil uji koefisien determinasi pada tabel 3

Tabel 3.

Hasil Uji Koefisien Determinan Model Summaryb

\begin{tabular}{llllll}
\hline Model & $\mathrm{R}$ & $\mathrm{R}$ Square & Adjusted R Square & Std. Error of the Estimate & Durbin-Watson \\
\hline 1 &, $485^{\mathrm{a}}$ & 236 &, 198 &, 388329 & 1,953 \\
\hline
\end{tabular}

a. Predictors: (Constant), AUDCHANGE, RECEIV, BDOUT, ACHANGE, LEV, ROA

b. Dependent Variable: F-SCORE

Sumber: Hasil Olah Data Output SPSS

Berdasarkan pengujian regresi yang dilakukan, diperoleh nilai $\mathrm{R}$ Square sebesar 0,236 menunjukkan bahwa variabel independen yang terdiri dari rasio perubahan total aset, rasio leverage, rasio return on assets, rasio piutang, proporsi jumlah dewan komisaris independen, dan pergantian auditor hanya mampu menjelaskan variabel dependen yaitu tingkat kecurangan laporan keuangan sebesar $23,6 \%$ sedangkan sisanya $76,4 \%$ dijelaskan atau dipengaruhi oleh variabel lain yang tidak termasuk dalam model regresi ini.

\section{Uji F}

Uji $F$ digunakan untuk menguji pengaruh semua variabel independen terhadap variabel dependen. Model regresi dikatakan fit apabila tingkat probabilitas F-statistik < 0,05. Berdasarkan hasil perhitungan perolehan nilai F hitung disajikan pada tabel 4 berikut ini:

Tabel 4.

Hasil Uji Signifikansi Simultan (Uji Statistik F) ANOVAa

\begin{tabular}{lllllll}
\hline Model & & Sum of Squares & Df & Mean Square & $F$ & Sig. \\
\hline \multirow{3}{*}{1} & Regression & 5,716 & 6 &, 953 & 6,318 &, $000^{\mathrm{b}}$ \\
\cline { 2 - 7 } & Residual & 18,548 & 123 &, 151 & & \\
\cline { 2 - 7 } & Total & 24,265 & 129 & & & \\
\hline
\end{tabular}

a. Dependent Variable: F-SCORE

b. Predictors: (Constant), AUDCHANGE, RECEIV, BDOUT, ACHANGE, LEV, ROA

Sumber: Hasil Olah Data Output SPSS 
Hasil perhitungan program SPSS diperoleh nilai $F$ hitung sebesar 6,318 serta nilai probabilitas sebesar 0,000 . Pada $F$ tabel dengan df1 (jumlah variabel-1) $=6$, dan df 2 ( $n$ k-1) atau 130-6-1 = 123 (n adalah jumlah data dan $\mathrm{k}$ adalah jumlah variabel independen), hasil diperoleh untuk $F$ tabel sebesar 2,17 (lihat pada lampiran 15) Karena $F$ hitung $>F$ tabel (6,318 > $2,17)$ maka dapat disimpulkan bahwa variabel independen secara bersama-sama mempunyai pengaruh terhadap kecurangan laporan keuangan (F-Score).

\section{Uji t}

Uji $t$ atau uji koefisien regresi secara parsial digunakan untuk mengetahui apakah secara parsial variabel independen berpengaruh secara signifikan atau tidak terhadap variabel dependen. Hasil uji statistik $t$ dapat dilihat pada tabel 5 berikut:

Tabel 5.

Hasil Perhitungan Uji Statistik t Coefficientsa

\begin{tabular}{|c|c|c|c|c|c|c|}
\hline \multirow{3}{*}{ Model } & & \multirow{2}{*}{\multicolumn{2}{|c|}{$\begin{array}{l}\text { Unstandardized } \\
\text { Coefficients }\end{array}$}} & \multirow{3}{*}{$\begin{array}{l}\text { Standardized } \\
\text { Coefficients } \\
\text { Beta }\end{array}$} & \multirow{3}{*}{$t$} & \multirow{3}{*}{ Sig. } \\
\hline & & & & & & \\
\hline & & $\mathrm{B}$ & Std. Error & & & \\
\hline \multirow{7}{*}{1} & (Constant) & ,219 & ,183 & & 1,197 & ,234 \\
\hline & ACHANGE & 652 & 304 & 184 & 2,148 & ,034 \\
\hline & LEV &,- 473 & 196 & -198 & $-2,411$ & ,017 \\
\hline & ROA & 1,951 & ,777 & 213 & 2,512 & ,013 \\
\hline & RECEIV & 1,084 & ,257 & ,341 & 4,219 &, 000 \\
\hline & BDOUT & 165 & 318 & 041 & ,521 & 603 \\
\hline & AUDCHANGE & ,068 & ,069 & ,079 & ,984 & ,327 \\
\hline
\end{tabular}

a. Dependent Variable: F-SCORE

Sumber: Hasil Olah Data Output SPSS

Dalam menyimpulkan uji $t$ diperlukan penentuan dari $t$ tabel yang dicari pada signifikansi $0,05 / 2=0,025$ (uji 2 sisi) dengan derajat kebebasan $\mathrm{df}=\mathrm{n}-\mathrm{k}-1$ atau 130-6-1 = 123 (n merupakan jumlah sampel, sedangkan $\mathrm{k}$ merupakan jumlah variabel independen). Hasil diperoleh untuk $t$ tabel sebesar 1,97944/1,97944. Kriteria pengujiannya yaitu:

1. Jika $-\mathrm{t}$ tabel $\leq \mathrm{t}$ hitung $\leq \mathrm{t}$ tabel maka Ho (variabel independen tidak berpengaruh terhadap variabel dependen) diterima.

2. Jika - $t$ hitung $<-t$ tabel atau $t$ hitung $>t$ tabel maka Ho (variabel independen tidak berpengaruh terhadap variabel dependen) ditolak.

Berdasarkan tabel 4.3 dapat disimpulkan bahwa:

1) Variabel $A C H A N G E$ memiliki nilai t hitung $>\mathrm{t}$ tabel $(2,148>1,979)$ maka $\mathrm{H}_{\mathrm{a} 1}$ diterima dan disimpulkan bahwa financial stability yang diproksikan dengan
ACHANGE berpengaruh positif dan signifikan terhadap kecurangan laporan keuangan.

2) Variabel LEV memiliki nilai -t hitung < -t tabel $(-2,411<-1,979)$ maka $\mathrm{H}_{02}$ diterima dan disimpulkan bahwa external pressure yang diproksikan dengan LEV berpengaruh negatif namun signifikan terhadap kecurangan laporan keuangan.

3) Variabel $R O A$ memiliki nilai $t$ hitung $>t$ tabel $(2,512>1,979)$ maka $\mathrm{H}_{\mathrm{a} 3}$ diterima dan disimpulkan bahwa financial targets yang diproksikan dengan ROA berpengaruh positif dan signifikan terhadap kecurangan laporan keuangan.

4) Variabel RECEIV memiliki nilai $t$ hitung $>t$ tabel $(4,219>1,979)$ maka $\mathrm{H}_{\mathrm{a} 4}$ diterima dan disimpulkan bahwa nature of industry yang diproksikan dengan RECEIV berpengaruh positif dan signifikan terhadap kecurangan laporan keuangan. 
5) Variabel BDOUT memiliki nilai t hitung $<\mathrm{t}$ tabel $(0,521<1,979)$ maka $\mathrm{H}_{05}$ diterima dan disimpulkan bahwa ineffective monitoring yang diproksikan dengan BDOUT berpengaruh positif namun tidak signifikan terhadap kecurangan laporan keuangan.

6) Variabel AUDCHANGE memiliki nilai $t$ hitung < $t$ tabel $(0,984<1,979)$ maka $\mathrm{H}_{06}$ diterima dan disimpulkan bahwa rationalization yang diproksikan dengan AUDCHANGE berpengaruh positif namun tidak signifikan terhadap kecurangan laporan keuangan.

\section{SIMPULAN DAN SARAN}

\subsection{Simpulan}

1. Financial Stability yang merupakan variabel proksi dari pressure yang diukur dengan rasio perubahan total aset (ACHANGE) berpengaruh positif signifikan terhadap tingkat risiko kecurangan laporan keuangan.

2. External Pressure yang merupakan variabel proksi dari pressure diukur dengan rasio leverage (LEV) yaitu debt to assets ratio berpengaruh negatif namun signifikan terhadap risiko kecurangan laporan keuangan.

3. Financial Targets yang merupakan variabel proksi dari pressure diukur dengan menggunakan rasio return on assets (ROA) berpengaruh positif dan signifikan terhadap risiko kecurangan laporan keuangan.

4. Nature of Industry yang merupakan variabel proksi dari opportunity yang diukur dengan rasio perubahan piutang (RECEIV) berpengaruh positif dan signifikan terhadap risiko kecurangan laporan keuangan.

5. Ineffective Monitoring yang merupakan variabel proksi dari opportunity yang diukur dengan proporsi dewan komisaris independen dengan jumlah dewan komisaris berpengaruh positif namun tidak secara signifikan terhadap risiko kecurangan laporan keuangan.

6. Auditor Change yang merupakan variabel proksi dari rationalization yang dihitung dengan variabel dummy berpengaruh positif namun tidak secara signifikan terhadap tingkat risiko kecurangan laporan keuangan.

\subsection{Saran}

Penelitian selanjutnya diharapkan dapat menggunakan sampel yang lebih banyak dari beberapa sektor sehingga diharapkan memperoleh hasil yang lebih maksimal. Penelitian selanjutnya diharapkan dapat menemukan variabel proksi lain yang dapat digunakan untuk mengetahui variabel lain yang diduga berpengaruh terhadap risiko terjadinya kecurangan laporan keuangan. Selanjutnya diharapkan dapat menemukan variabel lain untuk mengukur variabel rationalization selain variabel dummy supaya mendapatkan hasil yang lebih akurat dan beragam.

\section{DAFTAR PUSTAKA}

Ahmed, K dan J. Goodwin. 2007. An Empirical Investigation of Earnings Restatements by Australian firms. J.Accounting and Finance $47: 1-22$

American Institute of Certified Public

Accountans. 2001. Statement on

Auditing Standards. Diakses dari

http://www/aicpa.org/research/standard

s/auditattest/downloadabledocuments/a u-00316.pdf_ pada tanggal 14 Maret 2017

Annisya, Mafiana. 2016. Pendeteksian Fraudulent Financial Statement dengan Analisis Fraud Diamond (Studi Empiris Perusahaan Jasa Sektor Properti dan Real Estate yang Terdaftar di Bursa Efek Indonesia Tahun 2010-2014). Jurnal Bisnis dan Ekonomi Universitas Lampung Vol 23 (1): 72-89 ISSN: 1412-3126

Association of Certified Fraud Examiners (ACFE). 2002. Report to Nation.

Diakses dari

http://faculty.som.yale.edu/shyamsunde $\mathrm{r} /$ FinancialFraud/2002\%20Report $\% 200$ n\%20Fraud.pdfpada tanggal 15 Maret 2017

Christofel, Rendy. 2010. Moderasi Pengendalian Internal pada Hubungan 
Pengaruh Keadilan Organisasional Terhadap Tingkat Kecurangan (Fraud) (Studi pada Kantor Sekretariat Daerah Kota Semarang). Jurnal Fakultas Ekonomi, Universitas Diponegoro Semarang

Dechow, P.M. 2007. Predicting Material Accounting Misstatements. Working Paper. University of California, Berkele. Available at http://ssrn.com/abstract=997483 pada tanggal 15 Maret 2017

Fahrudin, Septian. 2014. Analisis Faktor-Faktor yang Mempengaruhi Pergantian Kantor Akuntan Publik (Studi Empiris pada Perusahaan Manufaktur yang Terdaftar di Bursa Efek Indonesia Periode 20082012). Skripsi Universitas Islam Negeri Syarif Hidayatullah Jakarta

Hanifa, S.I. 2015. Pengaruh Fraud Indicators Terhadap Fraudulent Financial Statement. Skripsi Fakultas Ekonomika dan Bisnis, Universitas Diponegoro Semarang

Hanum, Ivonna.N. 2014. Analisis Faktor-Faktor yang Mempengaruhi Fraudulent Financial Statement dengan Perspektif Fraud Triangle (Studi Empiris pada Perusahaan Sektor Property, Real Estate, dan Building Construction Tahun 2008-2012). Skripsi Universitas Lampung

Hernawan. 2010. Analisis Penelusuran Transaction Fraud dalam Perekayasaan Pelaporan Keuangan. Jurnal Ekonomi, Bisnis, dan Kewirausahaan. Vol 1 (2) ISSN: 20879954

Ghozali, Imam. 2013. Aplikasi Analisis Multivariate Dengan Program SPSS 21, Edisi Ketujuh. Semarang: Badan Penerbit Universitas Diponegoro

Gusnardi. 2012. Peran Forensic Accounting dalam Pencegahan Fraud. Pekbis Jurnal, Vol 4, No.1, Hal 17-25. Pekanbaru

Jansen, Michael C, William H. Meckling, 1976. Theory of The Firm, Managerial Behavior, Agency Cost and Ownership Structure. Journal of Financial
Economics. October, 1976. V.3 (4) : 305-360

Kasmir. 2013. Analisis Laporan Keuangan. Jakarta: PT Raja Grafindo Persada

Kurniawati, Ema. 2012. Analisis Faktor-Faktor yang Mempengaruhi Financial Statement Fraud dalam Perspektif Fraud Triangle. Skripsi Fakultas Ekonomika dan Bisnis, Universitas Diponegoro Semarang

Lou dan Wang. 2009. Fraud Risk Factor of The Fraud Triangle Assesing The Likelihood of Fraudulent Financial Reporting. Journal of Business and Economic Research. Vol 7 (2)

Marsono dan Rachmawati. 2014. Pengaruh Faktor-Faktor dalam Perspektif Fraud Triangle Terhadap Fraudulent Financial Reporting. Diponegoro Journal of Accounting. Vol 3 (2): 1-14

Molida, Resti. 2011. Pengaruh Financial Stability, Personal Financial Need, dan Ineffective Monitoring pada Financial Statement Fraud dalam Perspektif Fraud Triangle. Skripsi Fakultas Ekonomi, Universitas Diponegoro Semarang

Norbarani, Listiana. 2012. Pendeteksian Laporan Keuangan dengan Analisis Fraud Triangle yang Diadopsi dalam SAS No.99. Skripsi Fakultas Ekonomika dan Bisnis, Universitas Diponegoro Semarang

Pardosi, R. W. 2014. Analisis Fraud Diamond dalam Mendeteksi Kecurangan Laporan Keuangan pada Perusahaan Manufaktur di Indonesia dengan menggunakan Fraud Score Model (Tahun 2010 - 2013). Naskah Publikasi Ilmiah. Fakultas Ekonomi dan Bisnis, Universitas Lampung

Priyatno, Duwi. 2012. Cara Kilat Belajar Data dengan SPSS 20. Yogyakarta: Penerbit Andi

Ratmono, D. dan Diany, Y.A., 2014. Determinan Kecurangan Laporan Keuangan:Pengujian Teori Fraud Triangle. Diponegoro Journal of Accounting Vol. 1 (2) : 2-7 
Rezaee, Zabihollah. 2002. Financial Statement Fraud: Prevention and Detection. ISBN : 978-0-471-26915-1 336 pages. July 2002.

http://as.wiley.com/WileyCDA/WileyTitl e/productCd-0471269158.html diakses pada 20 April 2017

Rini, Viva Yustitia. 2012. Analisis Prediksi Potensi Risiko Fraudulent Financial Statement Melalui Fraud Score Model. Skripsi Fakultas Ekonomika dan Bisnis, Universitas Diponegoro Semarang

SAS No. 99. Corporate Governance and Firm Performance Advances in Financial Economis, Vol. 13 : 53-81

Setianto, Buddy. 2016. Benchmarking Ratio Keuangan Perusahaan Public Sector Property di BEI dengan Perusahaan Public di NYSE: Data laporan keuangan Q3 dan Q4 tahun 2015. BSK Capital. Diakses dari https://play.google.com/store/books/det ails?id=qA3UCwAAQBAJ\&rdid=bookqA3UCwAAQBAJ\&rdot=1\&source=gbs vpt_read\&pcampaignid=books_books earch_viewport pada tanggal 2 April 2017

Sihombing, K. S. dan Rahardjo. 2014. Analisis Fraud Diamond dalam Mendeteksi Financial Statement Fraud: Studi Empiris pada Perusahaan Manufaktur yang Terdaftar di Bursa Efek Indonesia (BEI) Tahun 2010-2012. Diponegoro Journal of Accounting Vol. 03 (02) ISSN (Online): 2337-3806

Skousen, C. J., Smith, K. R. and Wright, C. J. 2008. Detecting and Predecting Financial Statement Fraud: The Effectiveness of The Fraud Triangle and SAS 99. Available at http://ssrn.com/abstract=12954934 pada 20 Maret 2017

Skousen, C. J. and Twedt, Brady James. 2009. Fraud in Emerging Markets :A Cross Country Analysis. Available at http://ssrn.com/abstract=1340586 pada 24 Maret 2017
Sri Ayu, 2012. Pengaruh Profesionalisme Auditor Terhadap Pendeteksian Fraud Assets Missappropriation (Studi Kasus pada PT. Kereta Api Indonesia). Skripsi. Universitas Pendidikan Indonesia. Bandung

Sugiyono. 2005. Metode Penelitian. Alfabeta: Bandung

Sukirman dan Sari. 2013. Model Deteksi Kecurangan Berbasis Fraud Triangel (Studi Kasus Pada Perusahaan Publik di Indonesia). Jurnal Akuntansi dan Auditing Universitas Negeri Semarang, Vol. 09 (02) : 199-225

Sultan, B. M. K. 2005. The Construction Industry In Yemen Towards Economic Substainability. Disertasi Doktor. Australia: Queensland University of Technology

Suyanto. 2009. Fraudulent Financial Statement Evidence from Statement on Auditing Standard No. 99. Gajah Mada International Journal of Business,Vol. 11 (01) : 117-144

Turner et al., 2003. An Analysis of The Fraud Triangle. Diakses dari https://www.researchgate.net/publicatio n/237777981_An_Analysis_of the Fra ud_Triangle ) pada tanggal 2 April 2017

Warsidi dan Pramuka. 2009. Evaluasi Kegunaan Rasio Keuangan dalam Memprediksi Perubahan Laba di Masa yang Akan Datang. Jurnal Akuntansi Manajemen dan Ekonomi Vol 2 (1)

Widarti. 2015. Pengaruh Fraud Triangle Terhadap Deteksi Kecurangan Laporan Keuangan pada Perusahaan Manufaktur yang Terdaftar di Bursa Efek Indonesia (BEI). Jurnal Manajemen dan Bisnis Sriwijaya Vol $13(2)$

Laporan Keuangan Tahunan. Diakses dari http://www.idx.co.id/

Market Data. Diakses dari http://markets.ft.com 